\title{
CHANGES IN THE STRENGTH OF THE POLYMER CONCRETE USED IN THE ELECTROPLATING VATS UNDER OPERATIONAL LOAD
}

\author{
Lidia RADNA, Volodymyr SAKHAROV ${ }^{1}$ \\ University of Zielona Gora, Zielona Góra, Poland
}

\begin{abstract}
Due to the strong and aggressive electrolyte media and thermal load, design of the electroplating vats in the copper industry often relies on the resin concrete. The article presents the results of the strength tests of the polymer concrete based on the "Derakane" resin, used in the construction of electroplating vats. Samples were taken from the real vats - both new and 17-year old. Strength tests included compression and bending tensile strength test. To assess the effect of operational conditions the tests were performed on the same-age vats, some of which were never used while others were subjected to the operational load. During the operation, the vats sustained load of the anode and cathode weights, cyclic electrolyte loading with a temperatures up to $60^{\circ} \mathrm{C}$. As a result, it was noted that the operational conditions led to the increased strength of the polymer concrete material.
\end{abstract}

Keywords: electroplating vat, polymer concrete laboratory test, compressive, bending tensile strength, hardening

\section{INTRODUCTION}

Through the last sixty years there has been an increasing interest in polymer concrete or concrete in which the cement binder was completely replaced with synthetic resins. Over the years attempts have been pursued to modify its composition and the type of resins used in order to obtain concrete featuring the best possible strength properties. Resin concrete has very good chemical

\footnotetext{
1 Corresponding author: University of Zielona Gora, Faculty of Building, Architecture and Environmental Engineering, Z. Szafrana st 1, 65-516 Zielona Góra, Poland, e-mail: v.sakharov@ib.uz.zgora.pl, tel. +48 683282477
} 
resistance and high mechanical strength while allowing to quickly reach operational efficiency. It also has good adhesion properties with various building materials. Such material often contains quartz aggregate of high purity (exceeding 95\% $\mathrm{SiO} 2$ ). Depending on the eventual application of the resin concrete, different resins are used as bonding agents. The most frequently used one is solvent-free reactive epoxy resin. It is used as a bonding agent, which in the liquid state perfectly moistens the grains of the aggregate and - when hardened - forms a hardened mass which results in practically shrink-free curing process.

Classification of resin concretes varies - they could be classified for their strength, chemical resistance or temperature resistance. Resin concretes can be classified not only by the type of the resin bond used, but also by structure and volumetric (bulk) density, type of aggregate used and the maximum size of grains used [1]. Polymer concrete is suitable for virtually any application in construction as it is fully resistant to corrosion and erosion as well as features good resistance to weather conditions. Most polymer materials are more susceptible to aging with degradation and destruction processes. In many cases this leads to decreasing of the strength of construction with time. This research is aimed at the study of strength parameters of the polymer concrete construction after a long operational period. Resin concrete is widely used, especially where the strong chemical aggression occurs. Hence resin concretes are used in a heavy industry, chemical, marine industry, power generation sector but also in metallurgical industry and electro refining. To a significant extent resin concrete is also used in production of the sewage installation components used for the discharge of the aggressive sewage content.

In the copper industry electroplating vats used to be fabricated using plain concrete protected by a lead layer. Elements featuring such design would deteriorate rapidly due to the very aggressive media and thermal load. Thus electroplating vats made of resin concrete were introduced instead. The resins used for the polymer concrete are characterized by high thermal and chemical resistance to the action of, among others acids, solvents and alkaline solutions, especially substances such as sulfuric and hydrochloric acid at temperatures up to $90^{\circ} \mathrm{C}$. This study concentrated on the analysis of the polymer concrete based on the "Derakane" resin. They proved to be much more durable in use, despite of the increased chemical aggression of the electrolyte and the increased temperature of approximately $60^{\circ} \mathrm{C}$. New electroplating vats made of resin concrete can be seen in Fig. 1.

During operation electroplating vats are repeatedly subjected to the loads caused by replacement of electrolyte and electrodes, cleaning and recharging electroplating vats. 


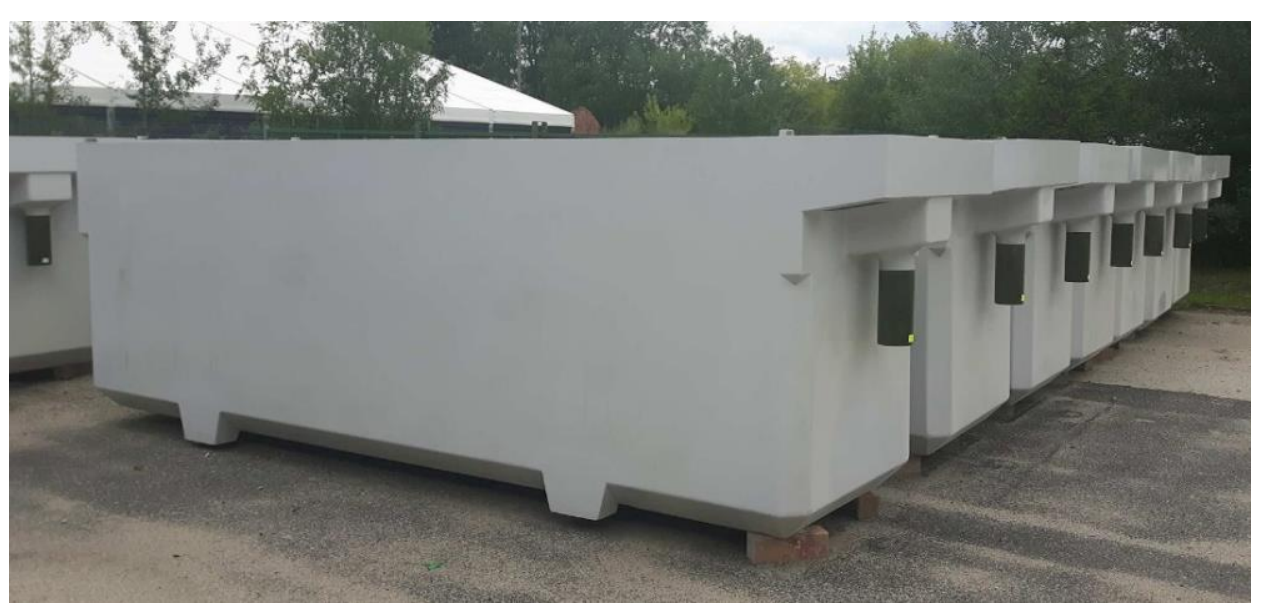

Fig. 1. Newly fabricated electroplating vats

Apart from the significant physical loads resulting from electrolyte as well as anodes and cathodes, an electroplating vat is also subjected to thermal loads ranging from $40^{\circ} \mathrm{C}$ to $55^{\circ} \mathrm{C}$ [5]. As already mentioned above, resin concrete made with certain resins of improved resistance is not resistant to rapid temperature changes (thermal shock); thermal shock causes cracks as a result of expansions exceeding resin concrete resistance, particularly around corners of an electroplating vat. Cyclic loads and temperature changes may result in material fatigue and may reduce overall material resistance, eventually leading to a malfunction or catastrophic event.

\section{STRENGTH TESTS}

Test samples were collected from undamaged parts of electroplating vats, decommissioned due to the discovered cracks (W-17-S) as well as from undamaged (without cracks) electroplating vats (W-17-NS) operated for 17 years and, finally, from the electroplating vats (WN) that were never used but were fabricated in the same period of time. The test of the strength conditions was carried out using INSTRON strength testing machine, type 8804 .

The test covered tensile strength testing of polymer concrete by bending $\left(R_{b z}\right)$ bars cut out from the bottom of electroplating vats provided for tests as well as testing compressive strength $\left(R_{c s}\right)$ determined for the cube-shaped test objects. The examined polymer concrete used in the fabrication of electroplating vats for the electro refining of copper cathodes, was subjected to a long term operation under unfavourable operational conditions. For the purpose of comparison the same parameters were determined from samples collected from the electroplating vats 
that were never used for electro refining of copper cathodes. To ensure the reliability of test results, six samples were tested.

\subsection{Bending tensile strength test}

Bending tensile strength $\left(R_{b z}\right)$ was determined based on bending test of bars cut out from provided elements of electroplating vats. The bar were cut out so that the longitudinal axis of the bar was parallel to the plane of electroplating vat bottom and the height of the test object $(h)$ was as close as possible to the average thickness of electroplating vat wall in the spot where the sample was collected. This way the height of the bar $h$ was close to its width $a$. The test was carried out by placing the test object on supports the span of which was $l=360 \mathrm{~mm}$ (Fig. 2).
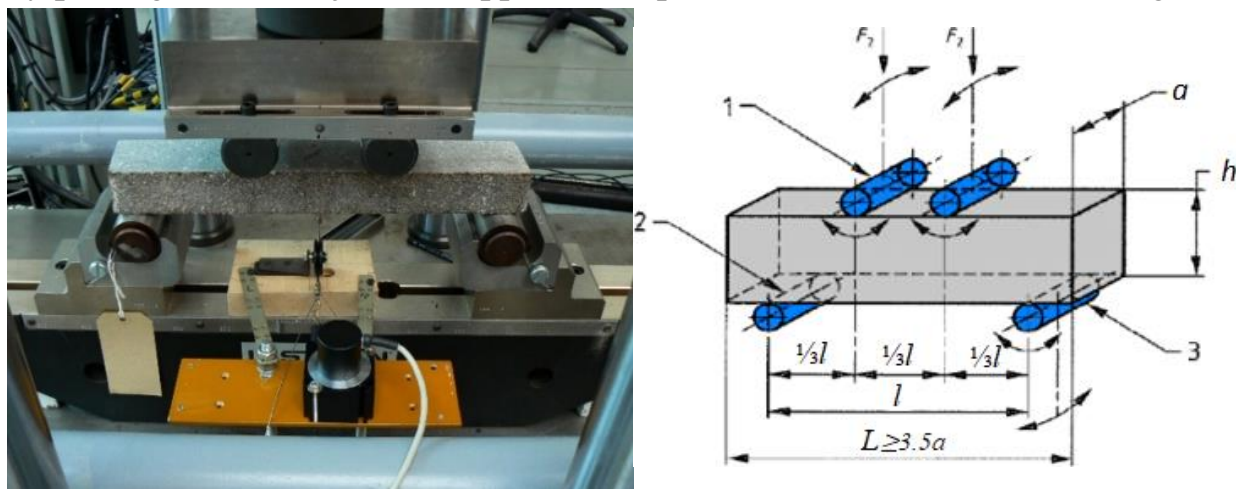

Fig. 2. Test object ready for bending tensile strength test, according to norm PN-EN 12390-5.

The bar was subjected to loads exerted by forces $F$ applied in the distance equal to $1 / 3 l$ from support, with rotating and tilting load rollers $(2,3)$. The direction of the load was parallel to the direction in which the mix was arranged. Bar dimensions $\mathrm{h}$ and a were read in the locations where the load rollers (1) were placed. Flexural strength was tested on samples according to PN-EN 12390-5, using the INSTRON type testing machine as the ratio of the bending moment to the section strength index.

Bending tensile strength $R_{b z}$ expressed as $\mathrm{N} / \mathrm{mm}^{2}(\mathrm{MPa})$ was determined using the following formula:

$$
R_{b z}=\frac{F l}{a h^{2}}
$$

where: $F$ - break force, [N], $l$ - span of supporting rollers, [mm], $a$ - bar width, [mm], $h$ - bar height, [mm].

The test results are presented in Table 1 . The analysis of the results showed that the bending tensile strength of the bars cut out from the used electroplating vats 
was approximately $46 \%$ higher than the strength of electroplating vats that had the same age but were never used (Fig. 3)

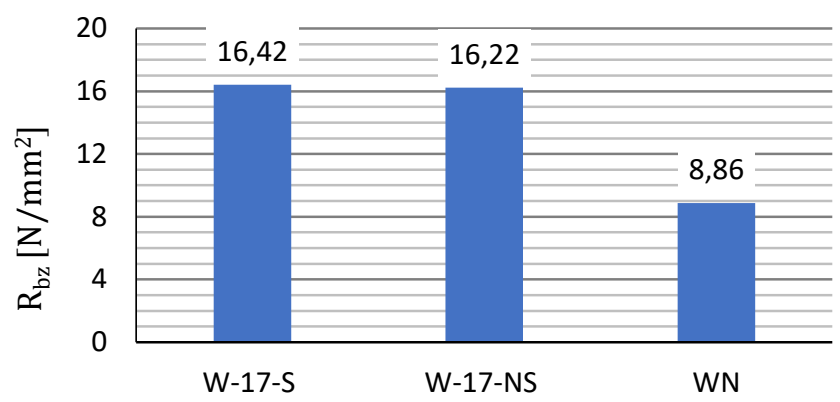

Fig. 3. Results of bending tensile strength test.

Table 1. The results of bending tensile strength test carried out for cuboid bars

\begin{tabular}{|c|c|c|c|c|c|}
\hline \multirow{2}{*}{$\begin{array}{c}\text { Electroplating } \\
\text { vat }\end{array}$} & \multicolumn{2}{|c|}{ Dimensions, mm } & \multirow{2}{*}{ Break force, $\mathbf{N}$} & \multicolumn{2}{|c|}{$R_{b z}, \mathbf{N} / \mathbf{m m}^{2}$} \\
\hline & $\mathbf{a}$ & $\mathbf{h}$ & & samples & average \\
\hline 1 & 2 & 3 & 4 & 5 & 6 \\
\hline \multirow{6}{*}{$\begin{array}{l}2 \\
1 \\
1 \\
1 \\
3\end{array}$} & 68.18 & 69.16 & 15414.66 & 17.02 & \multirow{6}{*}{$\begin{array}{c}\mathbf{1 6 . 4 2} \\
\pm 1.59 \\
\mathrm{~s}=1.51\end{array}$} \\
\hline & 68.32 & 68.51 & 13353.68 & 14.99 & \\
\hline & 68.62 & 69.73 & 13411.61 & 14.47 & \\
\hline & 66.33 & 67.65 & 14597.54 & 17.31 & \\
\hline & 67.73 & 69.41 & 14703.75 & 16.22 & \\
\hline & 69.00 & 68.90 & 16848.92 & 18.52 & \\
\hline \multirow{6}{*}{$\frac{n_{1}^{n}}{\frac{1}{1}}$} & 66.29 & 65.36 & 12381.23 & 15.74 & \multirow{6}{*}{$\begin{array}{l}\mathbf{1 6 . 2 2} \\
\pm 2.10 \\
\mathrm{~s}=2.00\end{array}$} \\
\hline & 68.90 & 66.22 & 10419.82 & 12.42 & \\
\hline & 67.71 & 68.76 & 15177.16 & 17.07 & \\
\hline & 61.20 & 68.16 & 14031.41 & 17.77 & \\
\hline & 70.75 & 71.79 & 17888.58 & 17.66 & \\
\hline & 69.02 & 70.14 & 15680.91 & 16.63 & \\
\hline 1 & 2 & 3 & 4 & 5 & 6 \\
\hline \multirow{6}{*}{$\frac{Z}{3}$} & 70.76 & 69.86 & 9015.77 & 9.40 & \multirow{6}{*}{$\begin{array}{c}\mathbf{8 . 8 6} \\
\pm 1.59 \\
\mathrm{~s}=0.92\end{array}$} \\
\hline & 69.69 & 70.82 & 9409.13 & 9.69 & \\
\hline & 70.54 & 70.43 & 8232.36 & 8.47 & \\
\hline & 71.35 & 70.68 & 9665.67 & 9.72 & \\
\hline & 71.64 & 69.90 & 8131.27 & 8.36 & \\
\hline & 71.65 & 70.05 & 7364.57 & 7.54 & \\
\hline
\end{tabular}

W-17-S - electroplating vat of polymer concrete operated for 17 years - with cracks

W-17-NS - electroplating vat of polymer concrete operated for 17 years - no cracks

WN- electroplating vat of polymer concrete - never used. 
Table 2. The results of compressive strength test carried out for cubic samples

\begin{tabular}{|c|c|c|c|c|c|c|c|c|c|}
\hline \multirow{2}{*}{$\begin{array}{l}\text { Electro- } \\
\text { plating vat }\end{array}$} & \multicolumn{4}{|c|}{ Sample dimensions, $\mathrm{mm}$} & \multicolumn{3}{|c|}{ Surface area, $\mathbf{m m}^{2}$} & \multirow{2}{*}{$\begin{array}{c}\text { Break } \\
\text { force, } \\
\quad \mathbf{N}\end{array}$} & \multirow{2}{*}{$\begin{array}{c}\text { Strength } \\
R_{c}^{s}, \\
\text { N/mm }\end{array}$} \\
\hline & a & b & c & d & $\begin{array}{c}\text { S1 } \\
\mathbf{a} \times \mathbf{b}\end{array}$ & $\begin{array}{c}\text { S2 } \\
\mathbf{x}\end{array}$ & $\mathbf{S}_{\text {sr }}$ & & \\
\hline \multirow{6}{*}{ W-17-S } & 67.31 & 67.60 & 67.26 & 68.76 & 4550.16 & 4624.80 & 4587.48 & 526469.7 & 114.76 \\
\hline & 68.68 & 67.79 & 69.16 & 68.71 & 4655.82 & 4751.98 & 4703.90 & 451274.9 & 95.94 \\
\hline & 68.52 & 67.79 & 69.16 & 68.71 & 4673.06 & 4604.62 & 4638.84 & 477697.8 & 102.98 \\
\hline & 68.58 & 65.37 & 68.52 & 66.29 & 4483.07 & 4542.19 & 4512.63 & 480290.4 & 106.43 \\
\hline & 67.68 & 67.36 & 67.90 & 68.17 & 4558.92 & 4628.74 & 4593.83 & 424427.1 & 92.39 \\
\hline & 69.96 & 68.65 & 69.81 & 67.77 & 4802.75 & 4731.02 & 4766.89 & 379145.8 & 79.54 \\
\hline \multicolumn{9}{|c|}{ Average value: $R_{c}^{s}=98.67 \mathrm{~N} / \mathrm{mm}^{2}$} & $\mathrm{~s}=\mathbf{1 2 . 2 5}$ \\
\hline \multirow{6}{*}{ W-17-NS } & 66.85 & 65.85 & 67.02 & 66.52 & 4402.07 & 4458.17 & 4430.12 & 491308.8 & 110.90 \\
\hline & 69.95 & 69.02 & 70.00 & 70.04 & 4827.95 & 4902.80 & 4865.38 & 527039.7 & 108.32 \\
\hline & 69.26 & 68.67 & 69.56 & 68.63 & 4756.08 & 4773.90 & 4764.99 & 457776.2 & 96.07 \\
\hline & 72.13 & 70.16 & 72.33 & 71.40 & 5060.64 & 5164.36 & 5112.50 & 529369.6 & 103.54 \\
\hline & 65.41 & 65.76 & 65.57 & 66.04 & 4301.36 & 4430.24 & 4365.80 & 437760.1 & 100.27 \\
\hline & 67.80 & 67.17 & 68.21 & 67.73 & 4554.13 & 4621.90 & 4588.02 & 463220.0 & 100.96 \\
\hline \multicolumn{10}{|c|}{ Average value: $R_{c}^{s}=103.34 \mathrm{~N} / \mathrm{mm}^{2}$} \\
\hline & 70.76 & 69.72 & 70.85 & 70.63 & 4933.39 & 5004.14 & 4968.77 & 370678.2 & 74.60 \\
\hline & 71.17 & 70.00 & 71.29 & 70.94 & 4981.90 & 5057.31 & 5019.61 & 427585.5 & 85.18 \\
\hline & 71.25 & 71.41 & 70.74 & 72.01 & 5087.96 & 5093.99 & 5090.98 & 404044.1 & 79.36 \\
\hline & 69.94 & 71.70 & 70.11 & 70.76 & 5014.70 & 4960.98 & 4987.84 & 384218.3 & 77.03 \\
\hline & 70.87 & 71.93 & 71.02 & 70.94 & 5097.68 & 5038.16 & 5067.92 & 378383.1 & 74.66 \\
\hline
\end{tabular}

W-17-S - electroplating vat of polymer concrete operated for 17 years - with cracks

W-17-NS - electroplating vat of polymer concrete operated for 17 years - no cracks

WN - electroplating vat of polymer concrete - never used. 
Polymer resin is a brittle material and its destruction is initiated by stress concentrations in the material. It can contain certain imperfections or defects during fabrication of electroplating vats. During the operation, due to the electrolyte load and a significant temperature variance on the wall sides, the high stresses will concentrate in such locations. When the strength is exceeded the appeared crack can grows up to the total collapse of the material.

\subsection{Compressive strength test}

Compressive strength $R_{c s}$ was determined using cube-shaped samples with crosssection oriented along the longitudinal walls of electroplating vats, which had a shape of a rectangular trapezoid. The sample was cut out so that its height (distance between planes being compressed on the machine) was equal to the average thickness of electroplating vat wall in the spot where the sample was collected. The direction of the load was parallel to the direction in which the mix was arranged in the form. The load applied to the sample uniformly with the constant kinematic load speed from the start of the sample until the sample destruction. The increment of the tension in the sample was approximately 0.5 $\mathrm{N} / \mathrm{mm}^{2}$.

The compression test results are shown in Table 2. The obtained results of compressive strength test demonstrated that the lowest values were achieved by the electroplating vats, which were never used while the strength of the used electroplating vats was higher by approximately $23.4 \%$ (Fig. 4). The reasons for the phenomenon of aging with strengthening could be attributed to the fact that over a long period of time (17 years) the electroplating vats were operated at elevated temperature $\left(60^{\circ} \mathrm{C} \pm 2^{\circ} \mathrm{C}\right)$ which acted as thermal finishing treatment of the resin concrete. This could have resulted in the improved polymerization of the resin which in turn improved strengths of the resin concrete.

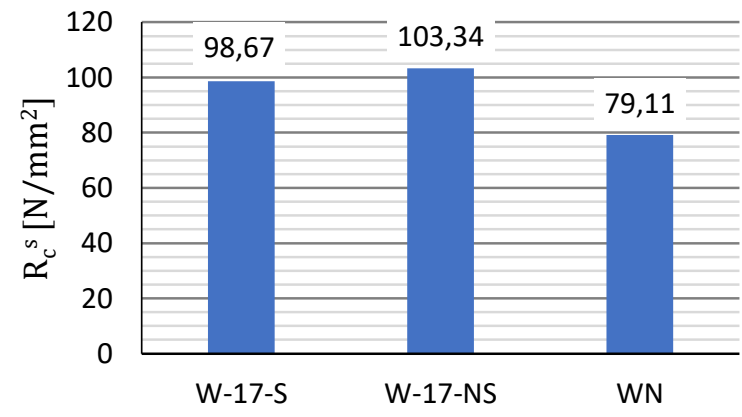

Fig. 4. The results of compressive strength determined for cubic samples

The results of the test show that the strength of resin concrete increases during operation of the concrete structure. Hence cracking of decommissioned 
electroplating vats may be caused by local concentrations of stresses such as stresses resulting from fatigue due to cyclic permanent loads and temperature, degradation and destruction. It is worth noticing that micro cracks [5] contribute to the penetration of liquid inside the material and this leads to an increased contact surface with aggressive environment and may result in faster degradation of the material in that location.

\section{FINAL CONCLUSIONS}

The following conclusions can be drawn on the basis of the test results:

1. Bending tensile strength of concrete used to fabricate electroplating vats that are exposed to loads from cathodes and anodes as well as electrolyte at approximately $60^{\circ} \mathrm{C}$ was higher when compared to the same-age electroplating vats that were not subjected to loads and the increase was significant, reaching approximately $46 \%$.

2. Compressive strength of the polymer concrete electroplating vats operated for the 17 years under load of cathodes and anodes as well as electrolyte at approximately $60^{\circ} \mathrm{C}$ was higher by $23.4 \%$ than that of the same-age electroplating vats which were never exposed to the operational load.

3. It is assumed that the main reason for increasing strength of samples of polymer concrete is the effect of elevated temperature, which results in the improved polymerization of the resin and better strength characteristics of the concrete.

4. The concrete cracking in the electroplating vats may be caused by the fatigue due to cyclic permanent and temperature loads, supplemented by the local degradation and destruction process.

\section{REFERENCES}

1. Czarnecki L. - Betony żywiczne. Arkady, Warsaw 1982.

2. Czarnecki L. - Betony polimerowe. International scientific bimonthly dedicated to chemistry and technology of bonding materials ans concrete. Year XV/LXXVII, March-April 2010. (www.cementwapnobeton.pl).

3. Hop T. - Betony polimerowe. Publication by Silesian University of Technology Gliwice 1992.

4. Kłapoć M. - Optymalizacja technologii i czasu bezpiecznego użytkowania wanien elektrolitycznych wykonanych z betonu żywicznego. Collective study, unpublished. Zielona Góra 2009.

5. Marcinowski J. - Główne przyczyny uszkodzeń wanien elektrolitycznych stosowanych w hucie miedzi. Przegląd budowlany 5/2010.

6. Mitzel Adam - Reologia betonu. Arkady, Warsaw 1972. 
7. Ohama Y. - Handbook of polymer-modified concrete and mortars. Noyes Publications, Park Ridge, New Jersey 1995.

8. Schweitzer $\mathrm{Ph}$. A. - Corrosion of polymers and elastomers. CRC Press, New York 2007 (2nd issue).

9. Tiitu M., Talo A., Forsen O., Ikkala O. - Polymer 2005, 46, No. 18, 6855.

\section{ZMIANY WYTRZYMAŁOŚCI BETONU POLIMEROWEGO STOSOWANEGO W WANNACH ELEKTROLITYCZNYCH POD OBCIĄŻENIEM TECHNOLOGICZNYM}

\section{Streszczenie}

Ze względu na silne i agresywne media elektrolityczne oraz obciążenie termiczne, projektowanie wanien elektrolitycznych w przemyśle miedziowym często opiera się na betonie żywicznym. W artykule przedstawiono wyniki badań wytrzymałościowych polimerobetonu na bazie żywicy "Derakane", stosowanych do budowy wanien elektrolitycznych. Badane próbki pobierano z prawdziwych wanien - zarówno nowych, jak i 17-letnich. Badania laboratoryjne obejmowały określenie wytrzymałości na ściskanie i zginanie. Aby ocenić wpływ warunków użytkowych, badania przeprowadzono na wannach o tym samym wieku, z których niektóre nigdy nie były użytkowane, podczas gdy inne były poddawane obciążeniu technologicznemu. Podczas pracy wanny utrzymywały one ładunek ciężaru anody i katody, cykliczne ładowanie elektrolitu w temperaturze do $60^{\circ} \mathrm{C}$. W rezultacie zauważono, że czas użytkowania wanny doprowadził do zwiększenia wytrzymałości polimerobetonu.

Słowa kluczowe: wanna elektrolityczna, badanie laboratoryjne polimerobetonu, ściskanie, zginanie, wytrzymałość na rozciąganie, hartowanie

Editor received the manuscript: 11.10.2017 